\title{
Educational achievement and gender differences: The role of the interaction between emotional stability and conscientiousness
}

Citation for published version (APA):

Wehner, C., \& Schils, T. (2019). Educational achievement and gender differences: The role of the interaction between emotional stability and conscientiousness. ROA. ROA Research Memoranda No. 005 https://doi.org/10.26481/umaror.2019005

Document status and date:

Published: 22/07/2019

DOI:

10.26481/umaror.2019005

Document Version:

Publisher's PDF, also known as Version of record

Please check the document version of this publication:

- A submitted manuscript is the version of the article upon submission and before peer-review. There can be important differences between the submitted version and the official published version of record.

People interested in the research are advised to contact the author for the final version of the publication, or visit the DOI to the publisher's website.

- The final author version and the galley proof are versions of the publication after peer review.

- The final published version features the final layout of the paper including the volume, issue and page numbers.

Link to publication

\footnotetext{
General rights rights.

- You may freely distribute the URL identifying the publication in the public portal. please follow below link for the End User Agreement:

www.umlib.nl/taverne-license

Take down policy

If you believe that this document breaches copyright please contact us at:

repository@maastrichtuniversity.nl

providing details and we will investigate your claim.
}

Copyright and moral rights for the publications made accessible in the public portal are retained by the authors and/or other copyright owners and it is a condition of accessing publications that users recognise and abide by the legal requirements associated with these

- Users may download and print one copy of any publication from the public portal for the purpose of private study or research.

- You may not further distribute the material or use it for any profit-making activity or commercial gain

If the publication is distributed under the terms of Article 25fa of the Dutch Copyright Act, indicated by the "Taverne" license above, 


\section{Maastricht University ROA}

Educational achievement and gender differences: The role of the interaction between emotional stability and conscientiousness

Caroline Wehner

Trudie Schils

\section{ROA Research Memorandum}

ROA-RM-2019/5

Researchcentrum voor Onderwijs en Arbeidsmarkt | ROA Research Centre for Education and the Labour Market / ROA 


\title{
Educational achievement and gender differences: The role of the interaction between emotional stability and conscientiousness
}

\author{
Caroline Wehner \\ Trudie Schils \\ ROA-RM-2019/5 \\ July 2019
}

Research Centre for Education and the Labour Market Maastricht University

P.O. Box 616, 6200 MD Maastricht, The Netherlands

$\mathrm{T}+31433883647 \mathrm{~F}+31433884914$

secretary-roa-sbe@maastrichtuniversity.nl www.roa.nl 


\section{Abstract \\ Educational achievement and gender differences: The role of the interaction between emotional stability and conscientiousness*}

The personality traits emotional stability and conscientiousness as well as the concept of gender are known to be predictive of educational achievement. Nevertheless, the interaction between these two traits and their relationship with both educational achievement and gender heterogeneity therein are far less explored and understood. We addressed this issue by using rich data from the British Cohort Study 1970 (BCS70) to targeting the relationship between personality as measured in adolescence and educational achievement in adulthood. We found that emotional stability was positively related to education outcomes for females, while conscientiousness was able to further boost their educational achievement. By contrast, these findings also indicated that less emotional stability was positively related to education outcomes for conscientious males. Our results suggest that an isolated examinations of the relationship between either emotional stability or conscientiousness and educational achievement while neglecting gender heterogeneity within these relations is likely misleading.

JEL classification: 120, 124, J16

Keywords: human capital, educational economics, personality differences, gender heterogeneity

Caroline Wehner

Institute for Vocational Education and

Training (BIBB)

Robert-Schuman-Platz 3

53175 Bonn

Germany

wehner@bibb.de

and IZA
Trudie Schils

Maastricht University

School of Business and Economics

P.O. Box 616

NL-6200 MD Maastricht

The Netherlands

t.schils@maastrichtuniversity.nl

* We would like to thank Lex Borghans, Ron Diris, Didier Fouarge, Bart Golsteyn, Harald Pfeifer and Daniela RohrbachSchmidt for their valuable comments. We further presented the article at the University College Dublin PhD Conference in Behavioural Science, at a Maastricht University Learning \& Work Poster session, and a Maastricht University Economics of Education seminar where we received helpful input from the participants. 


\section{Introduction}

Previous economic studies have used personality traits to predict educational outcomes. Results have typically shown that both emotional stability and conscientiousness are predictive of educational achievement. In addition, the literature points to important gender heterogeneity in education outcomes, which has partly been found to be related to gender differences in personality traits. However, little is known about the interaction effect between emotional stability and conscientiousness in the context of the relationship with educational achievement and any gender differences therein. It is important to obtain additional insight into these relationships because an isolated examination of one personality trait or the habit of neglecting the heterogeneous gender effects will likely achieve misleading results that may jeopardise the success of related (school) interventions.

This article discusses the interaction effect between emotional stability and conscientiousness among individuals aged 16 as it applies to educational achievement at the age of 30 . We also explore the relationship between shifted emotional stability and conscientiousness between the ages of 10 and 16 in relation to education outcomes in adulthood. Importantly, gender differences were analysed in each of these relationships. This was accomplished using data from the rich British Cohort Study 1970 (BCS70), which allowed us to trace individual history from birth to adulthood and included measurements for personality trait:1, cognitive ability, socioeconomic background in childhood, and educational achievement.

Our results confirmed the findings of previous studies. That is, emotional stability was positively related to education outcomes for females and conscientiousness significantly boosted educational success for both females and males. These findings suggest that emotional stability is less important for males than it is for females. Regard-

$1 \quad$ We assessed personality using the prominent Big-5 personality inventory (Goldberg, 1993: McCrae \& John, 1992), which contains the five following personality traits (OCEAN): Openness $(\mathrm{O})$, conscientiousness $(\mathrm{C})$, extraversion $(\mathrm{E})$, agreeableness, $(\mathrm{A})$ and neuroticism $(\mathrm{N})$. Here, emotional stability is defined as the reverse of neuroticism. Both terms are used throughout this article. 
ing the interaction effect between emotional stability and conscientiousness, we found that conscientiousness was able to mitigate some of the negative effects associated with lesser emotional stability among females. However, our results also indicate that less emotional stability is likely to boost educational achievement for conscientious males. An examination of the personality changes that occur in adolescence indicates that, for females, an increase in conscientiousness is particularly useful when there is less emotional stability. For conscientious males, however, we observed that an increase in emotional stability in adolescence was related to a decrease in educational achievement.

This study's contribution to the economic literature was twofold. First, we specifically addressed the interaction effect between emotional stability and conscientiousness in relation to educational achievement, which has not been studied within the current literature to our knowledge. Second, we explored gender differences in regard to this relationship. The resulting insight into this interaction effect and the related gender differences furthered our understanding of heterogeneity in educational success. As females and males exhibit different relationships between personality and educational achievement, our results also provided important input for policymakers. It may be more useful to implement policies that are specifically tailored for females and males. These should further consider individual levels of emotional stability and conscientiousness in adolescence. For instance, our findings indicate that it may be detrimental to boost emotional stability for more conscientious males in effort to improve educational achievement. This emphasises that, in order to understand educational outcomes, the role of personality and gender must be disentangled. It could thus be argued that educational policies and/or (school) interventions should not be developed as gender neutral or targeted at all personality types. Rather, they should take both personality and gender differences into account. However, an experimental study is needed to support this claim. In the next sections, we discuss the previous economic and psychological literature. We then introduce the data and present our results. Finally, we discuss our findings and provide a conclusion. 


\section{Literature}

\subsection{Personality and Educational Achievement}

Educational achievement is not only the result of cognitive ability among students, but is also related to their non-cognitive skills, including their personality traits. Studies on investments in (early) childhood education have shown the existence of a secondary dimension next to cognitive ability that is crucial for understanding the development of educational performance as well as the future success and behaviour of children. This includes labour market success, risky behaviour, and health (Borghans, Golsteyn, Heckman, \& Humphries, 2011; Campbell et al., 2014; Friiters, Johnston, \& Shields, 2014; Heckman. Humphries, \& Kautz, 2014; Heckman, Pinto, \& Savelvev, 2013; Lundborg. Nvstedt. \& Rooth, 2014; Poropat, 2009, 2014; Spengler et al., 2015; Spengler, Damian, \& Roberts, 2018).

The educational and psychological literature yields more information on the exact aspects of the non-cognitive factors that contribute to childhood educational achievement. Empirical studies have shown that the ability to plan and organise tasks, selfdiscipline, future goal orientation, the self-concept, daily learning routines, coping with stress, test anxietv. and control expectations are related to school performance (Corker \& Donnellan. 2012: Dignath \& Büttner. 2008: Hodis, Meyer, McClure, Weir, \& Walkey, 2011; Johnson \& Bloom, 1995; Lee, McInerney, Liem, \& Ortiga, 2010; McClure et al., 2011).

For example, some psychological theories point to varied coping styles (i.e., problemsolving thoughts and actions). Ursin and Eriksen's Cognitive Activation Theory of Stress, for example, contemplates that individuals react with arousal when they are confronted with a stimulus that is defined as the discrepancy between what the individual expects and what actually happens. The extent of stress and the way it affects student learning behaviours in school depends on individual stimuli and response outcome expectancies, which are based on previous experiences and learning; these are expected to differ between students with different personalities, including the elements 
of emotional stability and conscientiousness Cervone \& Pervin, 2014: Connor-Smith \& Flachsbart, 2007).

Low emotional stability (or neuroticism) relates to the degree to which a person experiences the world as threatening. There are several important facets to this issue, including anxiety, angriness, hostility, depression, self-consciousness, impulsiveness, and vulnerability (Hogan \& Hogan, 2007; Matthews, Deary, \& Whiteman, 2009). Persons with less emotional stability are more likely to report low self-esteem, worrying, insecurity, and nervousness (Cervone \& Pervin, 2014). They may also have heightened stress-reactivity and use emotion-focused coping strategies such as procrastination or avoidance (Campbell-Sills, Cohan, \& Stein, 2006; Connor-Smith \& Flachsbart, 2007). These coping strategies may reduce negative emotions and produce relief, which can be considered short-term gains.

For instance, a student with lower emotional stability is probably more stressed about living up to their teachers', parents', or own expectations and is thus expected to experience a higher level of arousal with respect to schoolwork and exams. This leaves the student with an uneasy feeling; they are also likely to engage in distracting activities to eliminate uncomfortable arousal (i.e., reduced concentration or avoidance). This reaction to stressful situations is based on short-term gain, but is likely to be outweighed by long-term costs (i.e., lower grades due to less effective schoolwork preparation). Thus, a self-fulfilling prophecy is created. Individuals with less emotional stability may be trapped in destructive patterns regarding expectations, feelings, and behaviours that are related to ineffective learning strategies and worsened educational outcomes (Wehner, 2018). Indeed, empirical studies have shown that less emotional stability is negatively related to student grades and participation (Almlund. Duckworth. Heckman. \& Kautz, 2011; Fouarge. Schils, \& de Grip, 2013;
Golstevn \& Schils, 2014; Lundberg, 2013; Mendolia \& Walker, 2014; Poropat,
2009, 2014; Ryan, Delaney, \& Harmon, 2013).

By contrast, conscientious students are more likely to apply problem-focused and engaged coping strategies (Connor-Smith \& Flachsbart, 2007). These students are 
also considered organised, persistent, and ambitious (Cervone \& Pervin, 2014). Here, conscientiousness refers to the degree to which a person is willing to comply with conventional rules. The most important facets in this context are competence, order, dutifulness, achievement, striving, self-discipline, and deliberation (Hogan \& Hogan, 2007; Matthews et al., 2009). Conscientious students are more likely to establish and refine an appropriate work organisation and engage in proper time management. They also have the self-discipline to realise their plans.

For example, a more conscientious student is more likely to complete and organise their learning materials, have a schedule prepared that splits learning content into smaller and better-digestible pieces, and stick to their learning schedule. The same student is thus more likely to have sufficient time to clarify open questions. Conscientiousness seems more related to behaviour rather than emotion and contributes to both effective learning strategies and higher school performance (Almlund et al., 2011; Golstevn \& Schils. 2014: Lundbero. 2013: MacCann, Lipnevich, Burrus, \& Roberts, 2012; Mendolia \& Walker, 2014; Poropat, 2009, 2014; Ryan et al., 2013; Saklofske, Austin, Mastoras, Beaton, \& Osborne, 2012).

While these studies have demonstrated a great deal of knowledge on the relationship between single personality traits and educational achievement, less is known about the interaction between different personality traits. For example, increased levels of conscientiousness may mitigate the negative relationship between less emotional stability and educational outcomes that apply to a higher probability of engagement and problem-focused coping. To our knowledge, these issues have not yet been systematically studied. This study therefore approached them accordingly.

\subsection{Emotional Stability, Conscientiousness, and Gender}

Gender differences are apparent when addressing educational outcomes. Many studies have reported that gender differences in educational achievement are related to specific subjects (e.g.. math or reading) (Bedard \& Cho. 2010: Cornwell, Mustard, \& van Parys, 2013; Ellison \& Swanson, 2010; Fryer \& Levitt, 2010; Husain \& Millimet, 
2009; Lai, 2010). Other studies have reported the existence of gender differences in test scores in relation to the importance of the test, with boys showing a larger difference in performance between low and high stakes tests than girls (Attali, Neeman, \& Schlosser, 2011).

Not only are gender differences observable in educational achievement, research has also indicated important gender differences in emotional stability and conscientiousness (Else-Quest. Hvde. Goldsmith. \& van Hulle, 2006; Fischer, Schult, \& Hell, 2013; Schmitt, Realo, Voracek, \& Allik, 2008). In general, conscientiousness levels are reported to be higher among females than males, especially for facets of conscientiousness that relate to increased organisation and diligence. Furthermore, females generally show lower levels of emotional stability than males. This includes lower levels of self-confidence and higher levels of anxiety. The extent of the observed gender differences change with the age of the observed population. Moreover, some non-cognitive skills (e.g., self-discipline or self-control) have been found to partially mediate gender differences in educational achievement (Cornwell et al.l. 2013: Duckworth \& Seligman, 2006; Duckworth et al.. 2015: Spinath. Eckert. \& Steinmavr. 2014: Spinath, Freudenthaler, \& Neubauer, 2010; Steinmayr \& Spinath, 2008).

Some studies have examined gender differences in the relationship between emotional stability, conscientiousness, and physical health (Friedman, Kern, \& Reynolds, 2010). On one hand, Suls and Bunde (2005) found that less emotional stability may be considered a risk factor for physical health problems (e.g., cardiovascular disease) related to anger, anxietv, and depression. On the other hand. Lee, Wadsworth, and Hotopf (2006) argued that anxiety may be protective because individuals exhibiting this condition may be particularly anxious and attentive about their health. This resulted in attention to the issue of how interaction between emotional stability and conscientiousness is a better predictor for physical health than emotional stability alone. Both Roberts, Smith. Jackson, and Edmonds (2009) and Turiano, Mroczek, Moynihan, and Chapman (2013) found that the combination of less emotional stability and more conscientiousness was positively related to physical health, particularly for males. This 
is because males exhibiting these behaviours are more likely to seriously consider the risk factors for physical health and initiate proper actions to prevent problems.

There is also a question as to whether similar gender differences are observed in the interaction between emotional stability and conscientiousness with respect to educational achievement. Following the lines of these articles on physical health, one may alternatively argue that less emotional stability may increase the fear of exam failure and therefore boost actions to prevent this risk among conscientious people. This issue is analysed in this paper.

\section{Data}

This article is based on the BCS702 2 Our analysis relied on a working sample restricted to cases with available information on cognitive ability among individuals aged 10, personality among those aged 10 and 16, educational achievement among those aged 30, gender, socioeconomic background, the region in which individuals lived at birth, and the age of the mother. Only individuals with no missing values were considered for analysis, thereby resulting in 4,203 observations.

The issue of possible sample selection was addressed by comparing the working sample with the unrestricted sample, as seen in Table 1. The procedure yielded that the working sample was selective. On average, people in the working sample were more emotionally stable and more conscientiousness, had higher cognitive ability, were from advantaged socioeconomic backgrounds, and had slightly older mothers. We thus likely estimated lower bound results so that these associations may have been even larger in the unrestricted sample 3

2 The following BCS70 waves were used: [dataset] Chamberlain, Chamberlain, and University of London (2013) (birth), Idatasetl Butler, Bynner, and University of London, Institute of Education, Centre for Longitudinal Studies (2014) (age 10), Idatasetl Butler, Bynner, and University of London, Institute of Education, Centre for Longitudinal Studies (2013) (age 16). [dataset] University of London, Institute of Education, Centre for Longitudinal Studies (2013) (age 30).

3 A multiple imputation of missing values with regard to the personality trait variables was performed to test the robustness of the results. Personality items were imputed if there were five or fewer missing values out of the 22 total items. The imputation of missing values resulted in an increase of the sample size to 4,908 observations. These results were consistent with the main 
Table 1: Descriptive Statistics

\begin{tabular}{|c|c|c|c|c|c|c|c|c|c|c|}
\hline \multirow[b]{2}{*}{ Variable Names } & \multicolumn{5}{|c|}{ Working Sample } & \multicolumn{5}{|c|}{ Unrestricted Sample } \\
\hline & $\mathrm{N}$ & Mean & SD & Min & $\operatorname{Max}$ & $\mathrm{N}$ & Mean & SD & Min & Max \\
\hline Highest NVQ Level (Age 30) & 4203 & 2.69 & 1.38 & 0.00 & 5.00 & 7704 & 2.56 & 1.42 & 0.00 & 5.00 \\
\hline Low Edu. Qualification (Age 30) & 4203 & 0.17 & 0.38 & 0.00 & 1.00 & 7704 & 0.20 & 0.40 & 0.00 & 1.00 \\
\hline Academic Degree (Age 30) & 4203 & 0.37 & 0.48 & 0.00 & 1.00 & 7704 & 0.34 & 0.48 & 0.00 & 1.00 \\
\hline Emotional Stability (ES, Age 16) & 4203 & 0.06 & 0.95 & -4.60 & 0.85 & 6768 & 0.00 & 1.00 & -4.60 & 0.85 \\
\hline Conscientiousness (C, Age 16) & 4203 & 0.06 & 0.94 & -4.76 & 0.71 & 6768 & -0.00 & 1.00 & -4.76 & 0.71 \\
\hline Agreeableness (A, Age 16) & 4203 & 0.07 & 0.90 & -7.69 & 0.52 & 6768 & 0.00 & 1.00 & -8.29 & 0.52 \\
\hline Extraversion (E, Age 16) & 4203 & 0.03 & 0.96 & -5.49 & 0.98 & 6768 & 0.00 & 1.00 & -5.49 & 0.98 \\
\hline More ES, More C (Age 16) & 4203 & 0.50 & 0.50 & 0.00 & 1.00 & 6768 & 0.48 & 0.50 & 0.00 & 1.00 \\
\hline More ES, Less C (Age 16) & 4203 & 0.13 & 0.34 & 0.00 & 1.00 & 6768 & 0.13 & 0.34 & 0.00 & 1.00 \\
\hline Less ES, More C (Age 16) & 4203 & 0.17 & 0.38 & 0.00 & 1.00 & 6768 & 0.17 & 0.38 & 0.00 & 1.00 \\
\hline Less ES, Less C (Age 16) & 4203 & 0.20 & 0.40 & 0.00 & 1.00 & 6768 & 0.22 & 0.41 & 0.00 & 1.00 \\
\hline Male & 4203 & 0.46 & 0.50 & 0.00 & 1.00 & 10046 & 0.50 & 0.50 & 0.00 & 1.00 \\
\hline Cognitive Ability (Age 10) & 4203 & 0.15 & 0.93 & -3.51 & 2.18 & 8586 & -0.00 & 1.00 & -4.10 & 2.18 \\
\hline Higher SES Parents (Birth) & 4203 & 0.20 & 0.40 & 0.00 & 1.00 & 10033 & 0.19 & 0.39 & 0.00 & 1.00 \\
\hline Region (Birth) & 4203 & 5.66 & 2.71 & 1.00 & 10.00 & 10046 & 5.69 & 2.64 & 1.00 & 11.00 \\
\hline Age Mother (Birth) & 4203 & 22.64 & 3.94 & 14.00 & 46.00 & 9989 & 22.33 & 3.96 & 13.00 & 47.00 \\
\hline
\end{tabular}

Source: BCS70, own calculations. SES refers to the term socioeconomic status.

\subsection{Educational Achievement}

We focused on educational achievement at the age of 30 because most individuals achieve their highest educational degree by that time. A total of three dependent variables were used in the analysis. First, the highest National Vocational Qualification (NVQ) at the age of 30 was analysed. The NVQ considers both vocational and academic qualifications. An NVQ score of 0 indicates that no qualification level was reached, while an NVQ score of 1 equals a low Ordinary Level (O level) or a Certificate of Secondary Education (CSE) between grades 2 through 5, an NVQ score of 2 includes a good O level, two or more AS (Advanced Subsidiary) levels, or one A

results and are available upon request. 
Figure 1: National Vocational Qualification (NVQ) scores by the Age of 30

Female
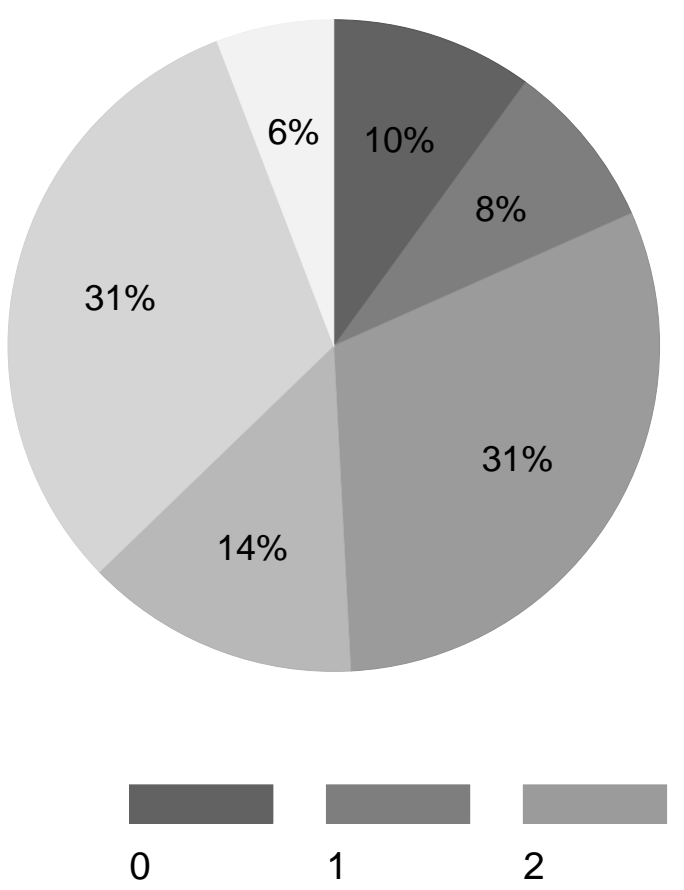

Male

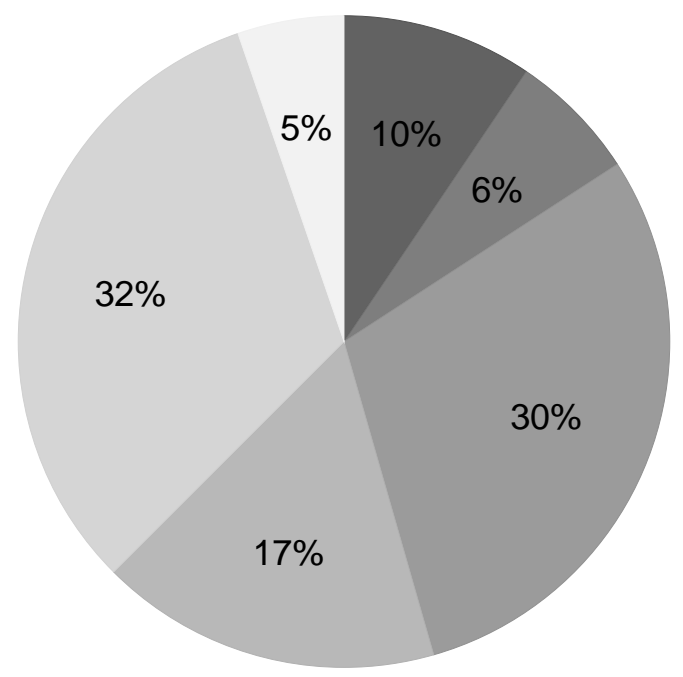

3
4

5

Source: BCS70. Own calculations, $n=4203($ females $=2279$; males $=1924)$.

(Advanced) level, an NVQ score of 3 equals more than one A level, an NVQ score of 4 refers to a bachelor's or master's degree or Postgraduate Certificate in Education (PGCE), and an NVQ score of 5 indicates higher degrees (e.g.. doctorates) (Dodgeon, Hancock, Johnson, \& Parsons, 2011).

Second, we created the binary variable 'low educational qualification' to specifically account for low educational achievers. The variable was measured 1 if respondents had only reached an NVQ score of 0 or 1 , while it was measured at 0 if respondents had reached an NVQ score of 2 or higher by the age of 30. Finally, a binary measure for obtaining an 'academic degree' was constructed. The variable was set to 1 if respondents had reached an NVQ score of 4 or 5 , while it was set to 0 if respondents had reached an NVQ score of $0,1,2$, or 3 by the age of 30 .

Figure 1 provides descriptive information about the distribution of educational achievements at the age of 30 . It reveals that, on average, $17 \%$ of the working sample 
respondents had only reached NVQ scores of 0 or 1 , while $46 \%$ had reached NVQ

scores of 2 or 3 , and $37 \%$ had reached NVQ scores of 4 or 5 by the age of 304 The percentage of females reaching low educational qualification (NVQ scores of 0-1) was slightly higher than that for males. However, both genders were equally likely to obtain academic degrees (NVQ scores of 4-5).

\subsection{Personality Traits}

We focused on the personality traits of neuroticism and conscientiousness because thev are known to be predictive of educational achievement. Following Matthews et al. (2009), neuroticism was defined as 'the degree to which a person experiences the world as threatening. Lower-order facets are anxiety, anger, hostility, depression, selfconsciousness, impulsiveness, and vulnerability' (p.25). The dimensions anxiety and impulsiveness were of particular interest because they are linked to emotion-focused problem solving, feelings of arousal, and pessimistic expectations. They are measured by the items 'irritable', 'miserable and tearful', 'requests must be met immediately', 'sullen or sulky', 'changes mood quickly and drastically', or 'outburst of temper unpredictable' (see Table 2).

Following Matthews et al. (2009), conscientiousness was defined as 'the degree to which a person is willing to comply with conventional rules. Low-order facets are competence, order, dutifulness, achievement, striving, self-discipline, and deliberation' (p.25). The dimensions 'self-discipline and deliberation' were of particular interest because they are linked to problem-focused coping strategies, finishing tasks, and reaching one's own goals. They were measured by the items 'cannot settle', 'inattentive, easily distracted', 'fails to finish things', and 'difficulty concentrating on task' (see Table 2).

$4 \quad$ The working sample was compared with data from Eurostat (2017) to check the plausibility of the results. Eurostat data from 2010 indicate that $22 \%$ of those aged 35 to 45 years had reached less than primary or lower secondary education, while $37 \%$ had finished tertiary education. Differences with regard to low achievers may be explained by the positive selection of respondents in the working sample. 
Table 2: Personality Traits at the Ages of 10 and 16

\begin{tabular}{|c|c|c|c|c|}
\hline $\begin{array}{l}\text { Personality } \\
\text { Trait }\end{array}$ & $\begin{array}{l}\text { Correlation } \\
\text { Age 10-16 }\end{array}$ & $\begin{array}{l}\text { Explained } \\
\text { Variance }\end{array}$ & $\begin{array}{l}\text { Cronbach's } \\
\text { Alpha }\end{array}$ & Items \\
\hline \multicolumn{5}{|c|}{ Emotional Stability } \\
\hline Age 10 & & $52.90 \%$ & 0.82 & R8. Irritable. \\
\hline Age 16 & 0.40 & $55.40 \%$ & 0.84 & $\begin{array}{l}\text { R9. Miserable and tearful. } \\
\text { C8. Requests must be met. } \\
\text { C12. Sullen or sulky. } \\
\text { C16. Changes mood quickly. } \\
\text { C17. Temper unpredictable. }\end{array}$ \\
\hline \multicolumn{5}{|c|}{ Conscientiousness } \\
\hline Age 10 & & $66.08 \%$ & 0.83 & R15. Cannot settle. \\
\hline Age 16 & 0.42 & $63.85 \%$ & 0.81 & $\begin{array}{l}\text { C3. Easily distracted. } \\
\text { C13. Fails to finish things. } \\
\text { C19. Difficulty concentrating. }\end{array}$ \\
\hline \multicolumn{5}{|c|}{ Agreeableness } \\
\hline Age 10 & & $48.04 \%$ & 0.82 & R3. Destroys belongings. \\
\hline Age 16 & 0.35 & $42.32 \%$ & 0.77 & $\begin{array}{l}\text { R4. Frequently fights. } \\
\text { R10. Takes others' belongings. } \\
\text { R14. Often disobedient. } \\
\text { R18. Often tells lies. } \\
\text { R19. Bullies other children. } \\
\text { C11. Interferes with others. }\end{array}$ \\
\hline \multicolumn{5}{|l|}{ Extraversion } \\
\hline Age 10 & & $37.13 \%$ & 0.56 & R5. Not much liked by others. \\
\hline Age 16 & 0.34 & $36.28 \%$ & 0.57 & $\begin{array}{l}\text { R6. Often worried. } \\
\text { R7. Rather solitary. } \\
\text { R16. Afraid of new things. } \\
\text { R17. Fussy or over-particular. }\end{array}$ \\
\hline
\end{tabular}

Source: BCS70, own calculations based on working sample $\mathrm{n}=4203$.

Note: Items are stated in original terms, but were reversely used in the analysis.

The BCS70 does not directly provide information about the personality traits of emotional stability, conscientiousness, agreeableness, or extraversion. In order to assess the personality of the individuals in the analvsis, this studv followed Prevoo and ter Weel (2015), who used BCS70 mother-rated behavioural items at the age of 16 and extracted emotional stability, conscientiousness, extraversion, and agreeableness from an initial set of 38 behavioural items. A principle component factor analysis 
Figure 2: Personality Traits at the Age of 16
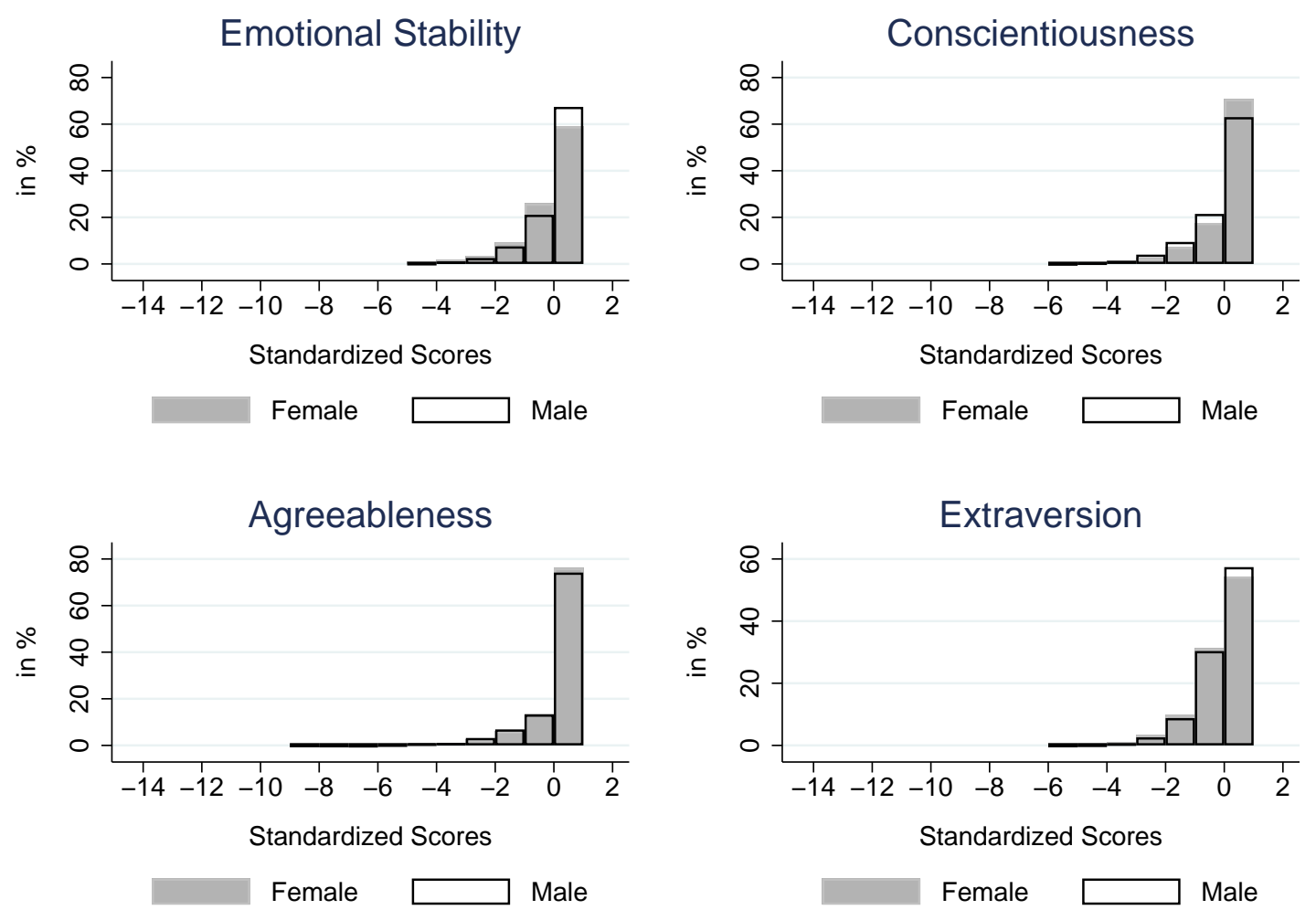

Source: BCS70. Own calculations, $n=4203$ (females $=2279$; males $=1924$ ).

was calculated using the proposed 22 standardised items to test the validity of the personality trait structure. The first four factors had eigenvalues larger than one and most items loaded highly on their respective factors. Each trait was assessed by extracting the first principle component from the set of items belonging to it. An overview of the reliability measures that correspond to the four personality traits is provided in Table 2. The results were comparable to those reported by Prevoo and ter Weel (2015).

This analysis used personality traits in three ways. First, they were used as continuous variables. Figure 2 presents the distribution of the personality traits according to gender at the age of 16 . The graph shows that females scored higher in conscientiousness, but scored lower in emotional stability at the age of 16 when compared to males; this is well-established in the literature (Schmitt et al., 2008). By contrast, 
we did not find gender differences in emotional stability at the age of 105. Table 2 shows a rank-order stability of around 0.40 for emotional stability and conscientiousness, which is lower than those reported by Robins, Fraley, Roberts, and Trzesniewski (2001). This may be due to the immense psychological, physical, and environmental changes individuals experience during puberty.

Second, four personality types were created to capture differences in emotional stability and conscientiousness at the age of 16 . Thereby, the distribution of the standardised variables emotional stability and conscientiousness were split at the mean (i.e., at zero). In addition, four above- and below-mean combinations of emotional stability and conscientiousness were constructed, as follows: (1) More emotionally stable and more conscientious, (2) more emotionally stable and less conscientious, (3) less emotionally stable and more conscientious, and (4) less emotionally stable and less conscientious. The procedure yielded that females and males represented the same share in the groups of (1) more emotional stability, more conscientiousness (both 50\%) and (4) less emotional stability, less conscientiousness (both 20\%). However, some known gender differences were observed in the other two groups. That is, relatively more females were in group (3) less emotionally stable, but there were more conscientious individuals (21\% females versus only $13 \%$ males), while relatively more males were in group (2) more emotionally stable, but there were less conscientious individuals (only $9 \%$ females versus $17 \%$ males).

Finally, we examined changes in personality trait types between the ages of 10 and 16. We thus used the four emotional stability and conscientiousness combinations described above and also based them on personality traits measured at age 10. Figure 3 presents the personality type change pattern. It shows that many individuals underwent personality characteristic changes between the ages of 10 and 16; this is in line with the current literature (Robins et al., 2001). The extent of change depended on which personality types we examined. Here, we found some interesting gender differ-

5 The distribution of personality traits at the age of 10 is available upon request or in Wehner (2018), p. 49. 
Figure 3: Personality Trait Changes between Ages 10 and 16

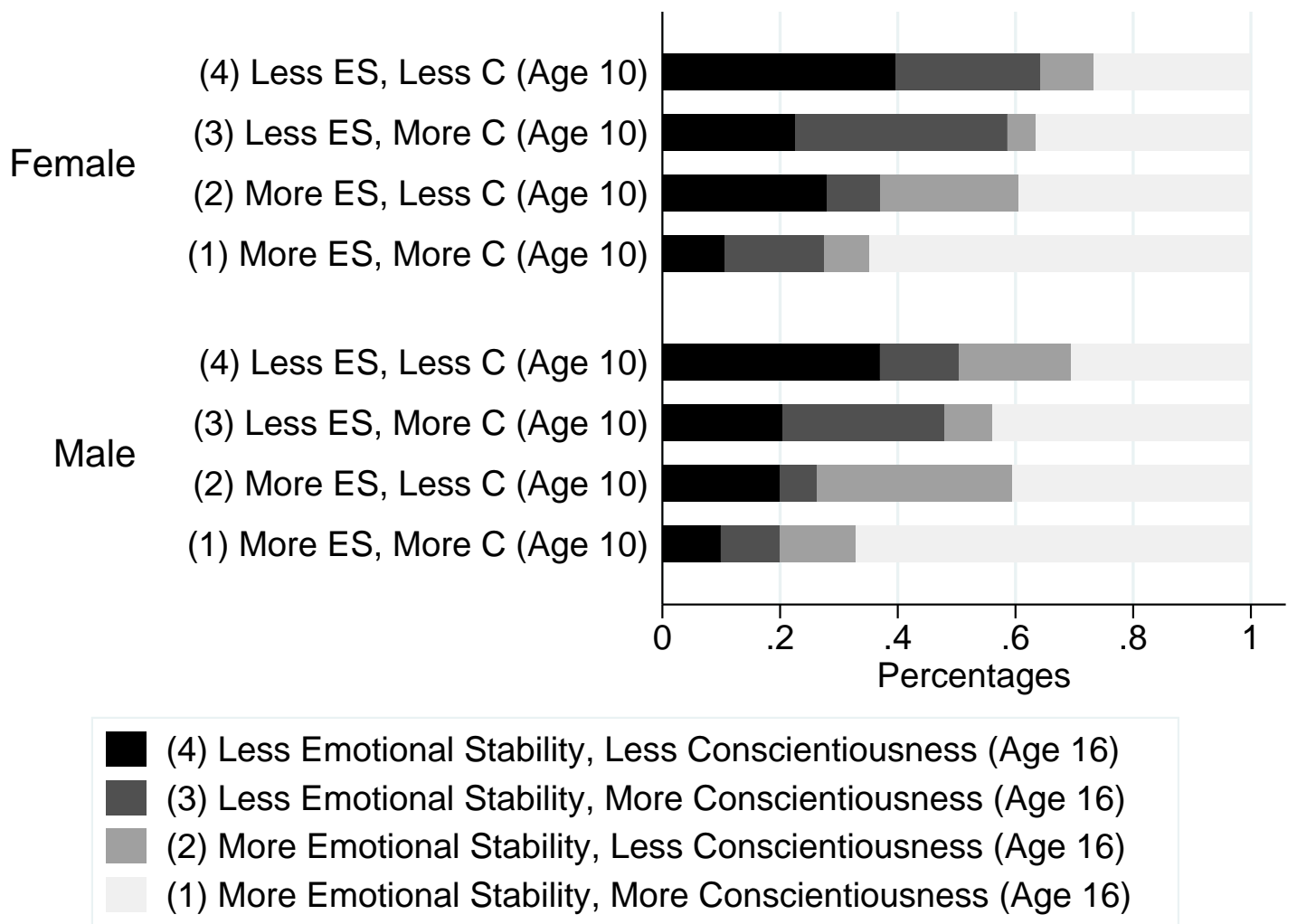

Source: BCS70. Own calculations, $n=4203$ (females $=2279$; males $=1924)$.

ences. When looking at group (4) with less emotionally stable and less conscientious individuals, we observed that about $40 \%$ of both males and females remained in this group at the age of 16 , while about $30 \%$ of each gender developed both traits, and some individuals changed in one trait. The figure depicts that females in this group were more likely to improve in conscientiousness, while males were more likely to improve in emotional stability.

This gender difference was also observed for group (3) with less emotionally stability and more conscientiousness at the age of 10. Males were more likely to improve in emotional stability between the ages of 10 and 16 than females. Females were more likely to remain in this group. For those who exhibited the opposite combination at age 10 (i.e., group (2) more emotional stability and less conscientiousness), we observed that about $40 \%$ of both males and females increased in conscientiousness. In both groups (2) and (1), we observed that females were more likely to decrease in 
emotional stability compared to males. In short, we primarily observed improvements in emotional stability for males, but less for females. Both seemed to improve in conscientiousness, but this was a bit more common among females.

\subsection{Additional Controls}

In addition to the measures discussed above, controls were included for the mother's age, mother's age squared, parental socioeconomic status, region of living at birth, and cognitive ability. Parental socioeconomic status was a binary variable (a value of 1 or 0$)$. It was coded as 1 if the highest parental occupational status was nonmanual, managerial, technical, or professional, but was coded as 0 if the child had a non-working single parent, parents who were unskilled or partly-skilled, or when the highest occupational status of the parents involved manual work. All variables are presented in Table 1 .

Table 3: Cognitive Ability Measures at the Age of 10

\begin{tabular}{ll}
\hline Educational Test & Components \\
\hline British Abilities Scale (BAS) & Self-completion; Non-verbal: Recall of digits \\
& $(34$ items $)$, matrices (28 items); Verbal: Word \\
& definitions (37 items), word similarities (42 \\
& items). \\
Shortened Edinburgh Reading Test (ERT) & Self-completion (64 items). \\
Friendly Maths Test (FMT) & $\begin{array}{l}72 \text { multiple choice questions. } \\
\text { Pictorial Language Comprehension Test (PLCT) }\end{array}$ \\
Vocabulary items, sequencing items, sentence \\
comprehension items (100 items). \\
Riagnostic Test
\end{tabular}

Source: BCS70, SN3723: 【dataset] Butler et al. (2014).

Following Prevoo and ter Weel (2015), cognitive ability was measured by using test scores at the age of 10 because it can be considered rank-order stable at that 
time (Lebel \& Beaulieu, 2011). Table 3 provides all test scores available at the age of 10. Results were analysed based on the Shortened Edinburgh Reading Test (ERT), the Friendly Maths Test (FMT), the Pictorial Language Comprehension Test (PLCT), and the diagnostic spelling test. This is because these tests contain the lowest numbers of missing values and measure a broad range of skills. The measure of cognitive ability was assessed according to a calculation of the share of correct answers per test. A standardised score (i.e., a mean of 0 and standard deviation of 1) was thus achieved out of these four shares per person.

\section{Results}

First, we present our results about the relationship between emotional stability, conscientiousness, and educational achievement. Second, we show the interaction effects between emotional stability and conscientiousness regarding education outcomes. We finalise the section by looking at personality trait changes in relation to educational success. We investigate gender differences in all subsections.

This analysis used ordinary least square (OLS) regression models for the continuous dependent variable 'NVQ' and linear probability regression methods for the binary dependent variables of reaching low educational qualification and obtaining an academic degree. In all regressions, controls were included for the respondent's other personality traits of agreeableness and extraversion at the age of 16, cognitive ability as measured at the age of 10, parental socioeconomic background and region of living at birth, mother's age, and mother's age squared. Robust standard errors were calculated to account for the possible problem of heteroscedasticity. 


\subsection{Personality and Educational Achievement}

Table 4: Correlation between Personality and Educational Qualifications

\begin{tabular}{lllllll}
\hline Personality Trait & $\begin{array}{l}\text { Female } \\
\text { NVQ } \\
(0-5)\end{array}$ & $\begin{array}{l}\text { Low Edu } \\
(1=0,1)\end{array}$ & $\begin{array}{l}\text { Academic } \\
(1=4,5)\end{array}$ & $\begin{array}{l}\text { NVQ } \\
(0-5)\end{array}$ & $\begin{array}{l}\text { Low Edu } \\
(1=0,1)\end{array}$ & $\begin{array}{l}\text { Academic } \\
(1=4,5)\end{array}$ \\
\hline $\begin{array}{l}\text { Emotional Stability } \\
\text { Age } 16\end{array}$ & .17 & -.12 & .14 & .06 & n.s. & .07 \\
Conscientiousness & & & & & & \\
Age 16 & .24 & -.15 & .21 & .23 & -.12 & .21 \\
\hline
\end{tabular}

Source: BCS70, own calculations based on working sample $\mathrm{n}=4203($ females $=2279$; males $=1924)$.

Note: The reported Spearman correlation coefficients were significant at the $5 \%$ level or higher; n.s. $=$ not significant. $\mathrm{NVQ}=$ National Vocational Qualification $($ Scale 0-5), Low Edu $=$ Low Educational Qualification (Binary: 1=0,1), Academic $=$ Academic Degree (Binary: $1=4,5)$ at the age of 30.

Table 4 provides an initial idea about the correlation between emotional stability as well as conscientiousness in adolescence and educational achievement in adulthood. It indicates that emotional stability was more positively correlated with educational achievement for females than for males. This was particularly observed when looking at only reaching low educational qualification. Conscientiousness was positively correlated with educational outcomes at nearly equal rates for both genders.

Table 5 shows that emotional stability in adolescence was significantly and positively related to educational achievement in adulthood among females. Females who scored 1 standard deviation higher in emotional stability at the age of 16 reached a 0.09 higher NVQ level, had an almost two percentage-point lower probability of reaching low educational qualification and a two percentage-point higher probability of holding an academic degree at the age of 30. However, the emotional stability male interaction terms indicated that emotional stability was significantly less related to NVQ level and low educational qualification for males when compared to females. For males, emotional stability only seemed to play a role in obtaining an academic degree. 
Table 5: Emotional Stability, Conscientiousness and Educational Qualification

\begin{tabular}{llll}
\hline Education Level (Age 30) $\ldots$ & $\begin{array}{l}\text { NVQ } \\
\text { Scale: 0-5) }\end{array}$ & $\begin{array}{l}\text { Low Edu } \\
\text { (Binary: 1=0,1) }\end{array}$ & $\begin{array}{l}\text { Academic } \\
(\text { Binary: 1=4,5) }\end{array}$ \\
\hline Emotional Stability (Age 16) & $\begin{array}{l}0.086^{* *} \\
(0.013)\end{array}$ & $\begin{array}{l}-0.019^{*} \\
(0.088)\end{array}$ & $\begin{array}{l}0.020^{*} \\
(0.070)\end{array}$ \\
Conscientiousness (Age 16) & $0.151^{* * *}$ & $-0.024^{* *}$ & $0.049^{* * *}$ \\
& $(0.000)$ & $(0.030)$ & $(0.000)$ \\
Emotional Stability $\times$ Male (Age 16) & $-0.134^{* * *}$ & $0.036^{* *}$ & -0.024 \\
& $(0.008)$ & $(0.021)$ & $(0.168)$ \\
Conscientiousness $\times$ Male (Age 16) & -0.011 & 0.007 & -0.008 \\
& $(0.799)$ & $(0.646)$ & $(0.608)$ \\
Male & $0.133^{* * *}$ & $-0.038^{* * *}$ & 0.021 \\
& $(0.000)$ & $(0.000)$ & $(0.124)$ \\
Cognitive Ability (Age 10) & $0.488^{* * *}$ & $-0.103^{* * *}$ & $0.136^{* * *}$ \\
& $(0.000)$ & $(0.000)$ & $(0.000)$ \\
Higher SES Parents (Birth) & $0.341^{* * *}$ & $-0.048^{* * *}$ & $0.142^{* * *}$ \\
\hline$N$ & $(0.000)$ & $(0.000)$ & $(0.000)$ \\
\hline$R^{2}$ & 4203 & 4203 & 4203 \\
\hline
\end{tabular}

Source: British Cohort Study (BCS70), own calculations.

Note: $p$-values in parentheses $* p<0.10,{ }^{* *} p<0.05,{ }^{* * *} p<0.01$. OLS (NVQ) and linear probability (Low Edu, Academic) regression methods using robust standard errors. The regressions included controls for mother's age, mother's age squared, region of living at birth, and the personality traits of agreeableness and extraversion as measured at the age of 16 .

For all females and individuals who had obtained academic degrees (regardless of gender), these results were in line with both the theoretical considerations and previous findings. School life is full of challenging situations and different stakes. In this context, less emotional stability is likely to be related to higher arousal, procrastination, and even avoidance. This likely forms an important channel for negative school experiences and earlier school dropout (De Paola \& Scoppa, 2015; Johnson \& Bloom, 1995). However, an alternative mechanism seemed to play a role for low-achieving males. 
This issue is further discussed in the next subsection.

By contrast, conscientiousness in adolescence was positively associated with educational achievement in adulthood for both genders. Students who scored 1 standard deviation higher in conscientiousness at the age of 16 reached a 0.15 higher NVQ level, had a 2.4 percentage-point lower probability of reaching low educational qualification, and an almost 5 percentage-point higher probability of holding an academic degree at the age of 30. These findings were in line with the literature (e.g. Almlund et al., 2011; Egan, Daly, Delanev. Bovce. \& Wood. 2017: Prevoo \& ter Weel. 2015: Roberts, Walton, \& Bogg, 2005) already showing that conscientiousness is a key to success in many domains of life, including education.

Finally, our results revealed that cognitive ability and parental socioeconomic status were positively related to educational achievement. This is a well-established result and therefore not discussed here in detail.

\subsection{Interaction Effect between Emotional Stability and Con- scientiousness}

We will discuss the interaction effect between emotional stability and conscientiousness with respect to educational achievement using multivariate regression methods. However, we first present the correlation coefficients between the personality trait combinations at the age of 16 - (1) more emotional stability, more conscientiousness, (2) more emotional stability, less conscientiousness, (3) less emotional stability, more conscientiousness, and (4) less emotional stability, less conscientiousness - and education outcomes at the age of 30 . 
Table 6: Personality Types and Mean Educational Qualification

\begin{tabular}{|c|c|c|c|c|c|c|c|c|c|}
\hline \multirow[t]{2}{*}{ Personality Type } & \multicolumn{3}{|l|}{ All } & \multicolumn{3}{|c|}{ Female } & \multicolumn{3}{|l|}{ Male } \\
\hline & NVQ & Low & Acad & NVQ & Low & Acad & NVQ & Low & Acad \\
\hline $\begin{array}{l}\text { More Emotional Stability, } \\
\text { More Conscientiousness }\end{array}$ & 2.92 & 0.14 & 0.45 & 2.93 & 0.14 & 0.45 & 2.91 & 0.14 & 0.45 \\
\hline $\begin{array}{l}\text { More Emotional Stability, } \\
\text { Less Conscientiousness }\end{array}$ & 2.35 & 0.22 & 0.26 & 2.32 & 0.23 & 0.25 & 2.37 & 0.21 & 0.26 \\
\hline $\begin{array}{l}\text { Less Emotional Stability, } \\
\text { More Conscientiousness }\end{array}$ & 2.76 & 0.16 & 0.40 & 2.62 & 0.18 & 0.37 & 3.02 & 0.11 & 0.45 \\
\hline $\begin{array}{l}\text { Less Emotional Stability, } \\
\text { Less Conscientiousness }\end{array}$ & 2.25 & 0.25 & 0.23 & 2.16 & 0.28 & 0.22 & 2.35 & 0.20 & 0.25 \\
\hline All & 2.69 & 0.17 & 0.37 & 2.65 & 0.18 & 0.37 & 2.72 & 0.16 & 0.38 \\
\hline
\end{tabular}

Source: BCS70, own calculations based on working sample $\mathrm{n}=4203$.

Note: $\mathrm{NVQ}=$ National Vocational Qualification $($ Scale 0-5). Low $=$ Low Educational Qualification (binary variable (1: 0-1; 0: 2-5)). Acad $=$ Academic Degree (binary variable (1: 4-5; 0:0-3)).

Table 6 presents the mean educational achievement by the four personality trait combinations. It illustrates that, on average, less emotionally stable and less conscientious females had the lowest educational achievement, while more emotionally stable and more conscientious females and males belonged to the group with the highest educational outcomes in adulthood. Interestingly, the educational achievement levels of less emotionally stable and more conscientious males slightly exceeded the outcomes for both more emotionally stable and more conscientious males regarding both NVQ and risk of low educational qualification. This again indicates that less emotional stability does not seem to be a penalty, but may actually be an advantage for males with more conscientiousness. To the contrary, we observed that less emotionally stable but more conscientious females had a lower probability of obtaining academic degrees and a higher probability of only reaching low educational qualifications when compared to both emotionally stable and conscientious females. 
Table 7: Interaction Effect between Emotional Stability and Conscientiousness

\begin{tabular}{llll}
\hline Education Level (Age 30) $\ldots$ & $\begin{array}{l}\text { NVQ } \\
\text { (Scale: 0-5) }\end{array}$ & $\begin{array}{l}\text { Low Edu } \\
(\text { Binary: 1=0,1) }\end{array}$ & $\begin{array}{l}\text { Academic } \\
(\text { Binary: 1=4,5) }\end{array}$ \\
\hline Emotional Stability (Age 16) & $\begin{array}{l}0.097^{* * *} \\
(0.003)\end{array}$ & $\begin{array}{l}-0.021^{* *} \\
(0.046)\end{array}$ & $\begin{array}{l}0.023^{*} \\
(0.030)\end{array}$ \\
Conscientiousness (Age 16) & $0.196^{* * *}$ & $-0.034^{* * *}$ & $0.063^{* * *}$ \\
& $(0.000)$ & $(0.007)$ & $(0.000)$ \\
Emotional Stability $\times$ Male (Age 16) & $-0.134^{* * *}$ & $0.040^{* * *}$ & -0.019 \\
& $(0.004)$ & $(0.004)$ & $(0.235)$ \\
Conscientiousness $\times$ Male (Age 16) & -0.045 & 0.016 & -0.017 \\
& $(0.322)$ & $(0.304)$ & $(0.279)$ \\
Emotional Stability $\times$ & $0.056^{* * *}$ & $-0.013^{* *}$ & $0.017^{* * *}$ \\
Conscientiousness (Age 16) & $(0.003)$ & $(0.046)$ & $(0.004)$ \\
Emotional Stability $\times$ & -0.044 & $0.020^{* *}$ & -0.007 \\
Conscientiousness $\times$ Male (Age 16) & $(0.137)$ & $(0.047)$ & $(0.425)$ \\
Male & $0.160^{* * *}$ & $-0.048^{* * *}$ & $0.027^{*}$ \\
\hline$N$ & $(0.000)$ & $(0.000)$ & $(0.067)$ \\
\hline$R^{2}$ & 4203 & 4203 & 4203 \\
\hline
\end{tabular}

Source: British Cohort Study (BCS70), own calculations.

Note: $p$-values in parentheses $* p<0.10,{ }^{* *} p<0.05,{ }^{* * *} p<0.01$. OLS (NVQ) and linear probability (Low Edu, Academic) regression methods used robust standard errors. The regressions included controls for mother's age, mother's age squared, region of living, and parental socioeconomic background at birth, the personality traits of agreeableness and extraversion as measured at the age of 16, and cognitive ability as measured at the age of 10 .

Table 7 shows a significant interaction effect between the continuous variables of emotional stability and conscientiousness on educational achievement among females. This means that the positive association between emotional stability and educational achievement was stronger with increasing conscientiousness. Alternatively, conscientiousness was able to compensate for low emotional stability. For males, the interaction effect between emotional stability and conscientiousness was only significant for ob- 
taining an academic degree.

Table 8: Personality Types and Educational Qualification

\begin{tabular}{llll}
\hline Education Level (Age 30) ... & $\begin{array}{l}\text { NVQ } \\
\text { (Scale: 0-5) }\end{array}$ & $\begin{array}{l}\text { Low Edu } \\
(\text { Binary: 1=0,1) }\end{array}$ & $\begin{array}{l}\text { Academic } \\
(\text { Binary: 1=4,5) }\end{array}$ \\
\hline More Emotional Stability, & $-0.357^{* * *}$ & 0.044 & $-0.133^{* * *}$ \\
Less Conscientiousness (Age 16) & $(0.000)$ & $(0.143)$ & $(0.000)$ \\
Less Emotional Stability, & $-0.184^{* * *}$ & 0.022 & $-0.046^{*}$ \\
More Conscientiousness (Age 16) & $(0.009)$ & $(0.261)$ & $(0.071)$ \\
Less Emotional Stability, & $-0.405^{* * *}$ & $0.085^{* * *}$ & $-0.130^{* * *}$ \\
Less Conscientiousness (Age 16) & $(0.000)$ & $(0.001)$ & $(0.000)$ \\
More Emotional Stability, & 0.120 & -0.030 & 0.043 \\
Less Conscientiousness $\times$ Male (Age 16) & $(0.329)$ & $(0.436)$ & $(0.305)$ \\
Less Emotional Stability, & $0.310^{* * *}$ & $-0.053^{*}$ & 0.060 \\
More Conscientiousness $\times$ Male (Age 16) & $(0.005)$ & $(0.075)$ & $(0.159)$ \\
Less Emotional Stability, & 0.184 & $-0.093^{* *}$ & 0.036 \\
Less Conscientiousness $\times$ Male (Age 16) & $(0.113)$ & $(0.011)$ & $(0.368)$ \\
Male & 0.032 & -0.006 & 0.001 \\
\hline$N$ & $(0.569)$ & $(0.684)$ & $(0.969)$ \\
\hline$R^{2}$ & 4203 & 4203 & 4203 \\
\hline
\end{tabular}

Source: British Cohort Study (BCS70), own calculations.

Note: $p$-values in parentheses $* p<0.10,{ }^{* *} p<0.05,{ }^{* * *} p<0.01$. OLS (NVQ) and linear probability (Low Edu, Academic) regression methods used robust standard errors. The regressions included controls for mother's age, mother's age squared, region of living and parental socioeconomic background at birth, the personality traits of agreeableness and extraversion as measured at the age of 16, and cognitive ability as measured at the age of 10 .

In Table 8, the interaction effect between emotional stability and conscientiousness is further explored by looking at the four personality types combining less versus more emotional stability and less versus more conscientiousness. The reference group includes more emotionally stable and more conscientious individuals.

For females, the results suggest that all combinations involving less emotional sta- 
bility or less conscientiousness yield lower NVQ levels and a lower probability of obtaining an academic degree when compared to the reference group. This is particularly likely to hold if females are less conscientious. For instance, more emotionally stable and less conscientious females scored 0.36 lower in the NVQ level and had a 13 percentage-point lower probability of obtaining an academic degree by the age of 30 . When less emotional stability was combined with less conscientiousness, even the probability of only reaching low educational qualification at the age of 30 was 9 percentage points higher than for the reference group. By contrast, less emotionally stable and less conscientious males had a 9 percentage-point lower risk of having low educational qualifications when compared to females with the same personality type.

Interestingly, except for obtaining an academic degree (where we found no significant gender differences), less emotionally stable but more conscientious males had significantly higher education outcomes when compared to females with the same personality characteristics. Their education outcomes were also slightly better than for males in the reference group (i.e., more emotionally stable and more conscientious males). This suggests that less emotional stability may even be beneficial for males when combined with more conscientiousness. Linking this result to the previously discussed findings about the relationship between emotional stability, conscientiousness, and physical health as cited by Friedman et al. (2010). Roberts et al. (2009). Suls and Bunde (2005), and Turiano et al. (2013), one could argue that less emotional stability seems to be a protective factor for conscientious males. This is because those individuals may be particularly anxious and attentive about their educational achievements, are more likely to take the risk factors for educational failure seriously, and tend to initiate proper action to prevent low educational achievement.

\subsection{Personality Change and Educational Achievement}

Table 9 provides the results on the relationship between a change in the emotional stability-conscientiousness combination between the ages of 10 and 16 and educational outcomes at the age of 30 . We only highlighted the changes that were considered most 
important with respect to educational outcomes as based on earlier results.

Model A shows the results for those in the group of less emotional stability and less conscientiousness at the age of 10 . For both genders, findings show that a simultaneous improvement in both emotional stability and conscientiousness is associated with higher educational achievement when compared to those who do not improve in these personality traits. An improvement in emotional stability was related to a lower probability of reaching low educational qualification for both genders by itself, while an increase in conscientiousness was related to a higher probability of obtaining an academic degree.

Models B and C (i.e., for groups with less of one personality trait and more of the other at age 10) did not reveal many significant coefficients related to the boost in the lower personality trait and educational achievement. The only exceptions were males who were low in emotional stability but high in conscientiousness at age 10 and who improved in emotional stability between the ages of 10 and 16. Our results suggest that these males are likely to experience a decline in their NVQ when compared to females with the same personality change, but also in comparison to less emotional stable but more conscientious males.

Finally, Model D shows the results for more emotionally stable and more conscientious individuals at the age of 10. It illustrates that a decrease in both personality traits between the ages of 10 and 16 was negatively related to educational achievement at the age of 30. In line with our previous results, we again observed that a decline in emotional stability in adolescence was associated with a higher NVQ at age 30 for conscientious males. 
Table 9: Personality Trait Change and Educational Qualification

\begin{tabular}{llll}
\hline Education Level (Age 30) $\ldots$ & NVQ & Low Edu & Academic \\
& $($ Scale: 0-5) & $($ Binary: 1=0,1) & $($ Binary: 1=4,5) \\
\hline
\end{tabular}

Model A: Less Emotional Stability (ES), Less Conscientiousness (C) at Age 10

\begin{tabular}{|c|c|c|c|}
\hline Change to More ES, More C (Age 16) & $\begin{array}{l}0.509^{* * *} \\
(0.001)\end{array}$ & $\begin{array}{l}-0.112^{* *} \\
(0.032)\end{array}$ & $\begin{array}{l}0.140^{* * *} \\
(0.004)\end{array}$ \\
\hline Change to More ES, Less C (Age 16) & $\begin{array}{l}0.314 \\
(0.109)\end{array}$ & $\begin{array}{l}-0.127^{*} \\
(0.068)\end{array}$ & $\begin{array}{l}0.037 \\
(0.573)\end{array}$ \\
\hline Change to Less ES, More C (Age 16) & $\begin{array}{l}0.199 \\
(0.216)\end{array}$ & $\begin{array}{l}-0.033 \\
(0.563)\end{array}$ & $\begin{array}{l}0.090^{* *} \\
(0.048)\end{array}$ \\
\hline $\begin{array}{l}\text { Change to More ES, More C (Age 16) } \\
\times \text { Male }\end{array}$ & $\begin{array}{l}-0.184 \\
(0.367)\end{array}$ & $\begin{array}{l}0.071 \\
(0.292)\end{array}$ & $\begin{array}{l}-0.036 \\
(0.594)\end{array}$ \\
\hline $\begin{array}{l}\text { Change to More ES, Less C (Age 16) } \\
\times \text { Male }\end{array}$ & $\begin{array}{l}-0.349 \\
(0.175)\end{array}$ & $\begin{array}{l}0.114 \\
(0.190)\end{array}$ & $\begin{array}{l}-0.028 \\
(0.742)\end{array}$ \\
\hline $\begin{array}{l}\text { Change to Less ES, More C (Age 16) } \\
\times \text { Male }\end{array}$ & $\begin{array}{l}0.263 \\
(0.264)\end{array}$ & $\begin{array}{l}-0.062 \\
(0.419)\end{array}$ & $\begin{array}{l}-0.026 \\
(0.748)\end{array}$ \\
\hline Male & $\begin{array}{l}0.354^{* * *} \\
(0.008)\end{array}$ & $\begin{array}{l}-0.131^{* * *} \\
(0.006)\end{array}$ & $\begin{array}{l}0.066^{*} \\
(0.098)\end{array}$ \\
\hline $\begin{array}{l}R^{2} \\
N\end{array}$ & 0.222 & $\begin{array}{l}0.113 \\
891\end{array}$ & 0.176 \\
\hline
\end{tabular}

Model B: Less Emotional Stability (ES), More Conscientiousness (C) at Age 10

\begin{tabular}{llll}
\hline Change to More ES, More C (Age 16) & $\begin{array}{l}0.154 \\
(0.285)\end{array}$ & $\begin{array}{l}-0.002 \\
(0.965)\end{array}$ & $\begin{array}{l}0.041 \\
(0.461)\end{array}$ \\
& & 0.058 & -0.125 \\
Change to More ES, More C (Age 16) & $-0.427^{*}$ & $(0.335)$ & $(0.154)$ \\
$\times$ Male & $(0.068)$ & -0.033 & 0.080 \\
Male & $0.316^{*}$ & $(0.446)$ & $(0.236)$ \\
& $(0.068)$ & 0.115 & 0.178 \\
\hline$R^{2}$ & 0.223 & 683 & \\
\hline
\end{tabular}


... Table 9 continued

\begin{tabular}{llll}
\hline Education Level (Age 30) ... & $\begin{array}{l}\text { NVQ } \\
(\text { Scale: 0-5) }\end{array}$ & $\begin{array}{l}\text { Low Edu } \\
(\text { Binary: } 1=0,1)\end{array}$ & $\begin{array}{l}\text { Academic } \\
(\text { Binary: } 1=4,5)\end{array}$ \\
\hline Model C: More Emotional Stability (ES), Less Conscientiousness (C) at Age 10 & \\
\hline Change to More ES, More C (Age 16) & 0.282 & -0.032 & 0.095 \\
& $(0.183)$ & $(0.632)$ & $(0.205)$ \\
Change to More ES, More C (Age 16) & 0.069 & -0.023 & 0.048 \\
$\times$ Male & $(0.790)$ & $(0.775)$ & $(0.601)$ \\
Male & -0.019 & -0.031 & -0.060 \\
& $(0.924)$ & $(0.642)$ & $(0.375)$ \\
$R^{2}$ & 0.215 & 0.149 & 0.163 \\
\hline
\end{tabular}

Model D: More Emotional Stability (ES), More Conscientiousness (C) at Age 10

\begin{tabular}{llll}
\hline Change to More ES, Less C (Age 16) & $-0.559^{* * *}$ & $0.089^{*}$ & $-0.211^{* * *}$ \\
& $(0.000)$ & $(0.053)$ & $(0.000)$ \\
Change to Less ES, More C (Age 16) & -0.119 & 0.006 & -0.029 \\
& $(0.198)$ & $(0.809)$ & $(0.393)$ \\
Change to Less ES, Less C (Age 16) & $-0.279^{* *}$ & 0.054 & $-0.111^{* * *}$ \\
& $(0.016)$ & $(0.153)$ & $(0.009)$ \\
Change to More ES, Less C (Age 16) & $0.402^{* *}$ & -0.073 & $0.137^{* *}$ \\
$\times$ Male & $(0.038)$ & $(0.230)$ & $(0.031)$ \\
Change to Less ES, More C (Age 16) & $0.334^{* *}$ & -0.045 & 0.077 \\
$\times$ Male & $(0.035)$ & $(0.252)$ & $(0.234)$ \\
Change to Less ES, Less C (Age 16) & 0.122 & -0.082 & 0.019 \\
$\times$ Male & $(0.504)$ & $(0.138)$ & $(0.771)$ \\
$N$ & & 0.004 & 0.173 \\
\hline
\end{tabular}

Source: British Cohort Study (BCS70), own calculations.

Note: $p$-values in parentheses ${ }^{*} p<0.10,{ }^{* *} p<0.05,{ }^{* * *} p<0.01$. OLS (NVQ) and linear probability (Low Edu, Academic) regression methods used robust standard errors. The regressions included controls for mother's age, mother's age squared, region of living and parental socioeconomic background at birth, and cognitive ability as measured at the age of 10 . 


\section{Discussion and Conclusion}

Both economic and psychological studies have shown that differences in education outcomes are related to gender and personality traits such as emotional stability and conscientiousness. Findings indicate that the observed gender differences in educational outcomes largely depend on the specific circumstances under analysis, including the subject tested, importance of the test, and age at which the tests are taken. It is further shown that less emotional stability is predominantly negatively related to educational outcomes, while conscientiousness is almost seen as a guarantor of desirable results. However, less is known about the interaction effect between emotional stability and conscientiousness in relation to educational achievement and the gender differences therein. This study directly addressed this knowledge gap. Improved insight into these relationships could enhance our knowledge of gender differences as they relate to educational outcomes. This information can also be used to develop tailored (school) interventions that consider personality and gender differences when providing support to low educational achievers.

First, our results were mainly consistent with those in the established education literature. Interestingly, our analysis showed that the bivariate relationship between emotional stability and educational outcomes was stronger for females than for males. For males, this relationship was only observed in relation to obtaining an academic degree; it seemed less valid in preventing low educational qualification. In other words, some degree of emotional instability may help males move into the middle group instead of the bottom group of the educational achievement distribution scale. By contrast, we found no gender differences in the observed bivariate positive association between conscientiousness and educational outcomes.

Second, our results revealed a significant interaction effect between the continuous variables of emotional stability and conscientiousness on educational achievement among females. That is, the positive association between emotional stability and educational achievement was stronger with increased conscientiousness. This is likely related to a lower tendency to procrastinate, improved problem-solving skills and more 
self-discipline in challenging situations (De Paola \& Scoppa, 2015; Johnson \& Bloom, 1995). For males, the interaction effect of conscientiousness was only observed at the upper end of the ability distribution.

We also analysed the interaction effect between emotional stability and conscientiousness by constructing four different personality types at the age of 16, as follows: (1) More emotional stability, more conscientiousness, (2) more emotional stability, less conscientiousness, (3) less emotional stability, more conscientiousness, and (4) less emotional stability, less conscientiousness. Our findings suggest that females with less conscientiousness at age 16 in combination with less emotional stability have the lowest educational outcomes at the age of 30 . The highest educational achievement at the age of 30 was observed for emotionally stable females who reported more conscientiousness at the age of 16, which again points to an important interaction effect between emotional stability and conscientiousness among these individuals. For males, we found that less emotional stability may even be beneficial for educational achievement when combined with more conscientiousness.

Finally, we analysed personality changes between the ages of 10 and 16 and their relationship to educational achievement. Here, we found increased emotional stability among males, but less such among females. Both males and females were likely to increase in conscientiousness (this was slightly more common among females). Moreover, we generally observed that an increase of one or both personality traits was related to an increase in educational achievement among less emotionally stable and less conscientious individuals. Those that reported more of both traits at age 10 were best kept in this group at age 16. This is because any reduction of one or both traits was negatively related to educational outcomes at the age of 30 for both males and females. The only exceptions were more emotionally stable and more conscientious males, who were likely to experience increased educational achievement after decreasing in emotional stability between the ages of 10 and 16. Conversely, our results also indicated that an increase in emotional stability during this life phase was related to decreased educational achievement among initially less emotionally stable and more 
conscientious males.

Our study yielded three important insights for educational research and related policies. First, our findings reemphasised the important role of conscientiousness for the educational achievements of both females and males. Our results also indicated an underestimated importance of improving skills related to conscientiousness if analysed in isolation. This is due to a neglection of the benefits that accrue through positive interactions with emotional stability in the higher educational achievement distributions for males and, in general, for females.

Second, our analysis revealed heterogeneity in the relationship between emotional stability and educational achievement according to gender and the ability distribution. On the one hand, our findings suggested that increased emotional stability was likely beneficial in terms of educational outcomes among females. This was especially interesting given the fact that, on average, females reported lower levels of emotional stability when compared to males at the age of 16 . The mechanism behind this finding may be that females are more likely to respond to low emotional stability with avoidance or procrastination behaviours in school. On the other hand, interventions aimed at improving emotional stability should not target more conscientious males at the lower end of the ability distribution. It seems that more emotionally stable and more conscientious males have a higher risk of (early) school dropout than less emotionally and more conscientious males. An explanatory approach for this finding may be found based on how less emotionally stable males tend to work harder and prepare more carefully in challenging school situations because they are more likely to fear negative results or exam failures. This is in line with current health literature and is especially relevant for interventions (e.g., those for (early) school dropout, where males are strongly overrepresented).

Third, females and males showed different relationships between personality and educational achievement. Thus, tailored gender-based interventions should consider individual levels of emotional stability and conscientiousness in adolescence. This may boost educational outcomes better than gender and personality interventions that are 
more neutral. However, an experimental study is needed to support this claim.

Regardless, results indicate that adolescence is an age of opportunity. Findings from neuroscience studies demonstrate that this life phase is also important in terms of brain plasticity. This is especially true for elements related to cognitive development such as planning and reasoning, thereby suggesting that school interventions may raise educational achievements in both adolescence and adulthood (Reyna, Chapman, Dougherty, \& Confrey, 2012; Steinberg, 2014). School interventions also guarantee high and long-term coverage in addition to lower costs because they enable the joint use of different public services (see e.g. Carta, Di Fiandra, Rampazzo, Contu, \& Preti, 2015). Future research can build on our findings. Future related studies should conduct random controlled trails to develop effective and efficiently tailored school programs. It is also important to remember that the practice of transferring research-oriented studies into school settings is not always unproblematic. For instance, teachers may not understand all interventional features and different school environments may not necessarily fit the study design (Borghans, Schils, \& de Wolf, 2016). Careful interdisciplinary guidance is thus essential during development processes, empirical analyses, and the implementation of school programs. 


\section{References}

Almlund, M., Duckworth, A. L., Heckman, J., \& Kautz, T. (2011). Personality Psychology and Economics. In E. A. Hanushek, S. Machin, \& L. Woessman (Eds.), (Vol. 4, p. 1-181). Amsterdam: Elsevier. doi: 10.1016/B978-0-444-53444 $-6.00001-8$

Attali, Y., Neeman, Z., \& Schlosser, A. (2011). Rise to the Challenge or not Give a Damn: Differential Performance in High vs. Low Stakes Tests. IZA Discussion Paper, 5693. doi: 10419/51974

Bedard, K., \& Cho, I. (2010). Early Gender Test Score Gaps Across OECD Countries. Economics of Education Review, 29, 348-363. doi: 10.1016/j.econedurev.2009 .10 .015

Borghans, L., Golsteyn, B. H., Heckman, J. J., \& Humphries, J. E. (2011). Identification Problems in Personality Psychology. Personality and Individual Differences, 51 (3), 315-320. doi: 10.1016/j.paid.2011.03.029

Borghans, L., Schils, T., \& de Wolf, I. (2016). Experimentalism in Dutsch Education Policy. In T. Burns \& F. Köster (Eds.), Governing education in a complex world (p. 187-205). Paris: OECD Publishing. doi: 10.1787/9789264255364-11-en

Campbell, F., Conti, G., Heckman, J., Moon, S., Pinto, R., Pungello, E., \& Pan, Y. (2014). Early Childhood Investments Substantially Boost Adult Health. Science, 343, 1478-1485. doi: 10.1126/science.1248429

Campbell-Sills, L., Cohan, S. L., \& Stein, M. B. (2006). Relationship of Resilience to Personality, Coping, and Psychiatric Symptoms in Young Adults. Behaviour Research and Therapy, 44(4), 585-599. doi: 10.1016/j.brat.2005.05.001

Carta, M. G., Di Fiandra, T., Rampazzo, L., Contu, P., \& Preti, A. (2015). An Overview of International Literature on School Interventions to Promote Mental Health and Well-being in Children and Adolescents. Clinical Practice \& Epidemiology in Mental Health, 11, 16-20. doi: 10.2174/1745017901511010016

Cervone, D., \& Pervin, L. (2014). Personality psychology (12th ed.). New York: Wiley. 
Connor-Smith, J. K., \& Flachsbart, C. (2007). Relations between Personality and Coping: A Meta-Analysis. Journal of Personality and Social Psychology, 93(6), 1080-1107. doi: 10.1037/0022-3514.93.6.1080

Corker, K. S., \& Donnellan, M. B. (2012). Setting Lower Limits High: The Role of Boundary Goals in Achievement Motivation. Journal of Educational Psychology, 104, 138-149. doi: 10.1037/a0026228

Cornwell, C., Mustard, D., \& van Parys, J. (2013). Noncognitive Skills and the Gender Disparities in Test Scores and Teacher Assessments: Evidence from Primary School. Journal of Human Resources, 48(1), 236-264. doi: 10.3368/jhr.48.1.236

[dataset] Butler, N., Bynner, J., \& University of London, Institute of Education, Centre for Longitudinal Studies. (2013). $19^{7} 70$ British Cohort Study: Sixteen-Year Follow-Up, 1986. 5th Edition. Colchester, Essex: UK Data Archive, May 2013. SN: 3535. doi: 10.5255/UKDA-SN-3535-2

[dataset] Butler, N., Bynner, J., \& University of London, Institute of Education, Centre for Longitudinal Studies. (2014). 1970 British Cohort Study: Ten-Year FollowUp, 1980. 5th Edition. Colchester, Essex: UK Data Archive, July 2014. SN: 3723. doi: 10.5255/UKDA-SN-3723-3

[dataset] Chamberlain, R., Chamberlain, G., \& University of London. (2013). Institute of Education. Centre for Longitudinal Studies, 1970 British Cohort Study: Birth and 22-Month Subsample, 1970-1972. 3rd Edition. UK Data Service. SN: 2666. doi: $10.5255 /$ UKDA-SN-2666-2

[dataset] University of London, Institute of Education, Centre for Longitudinal Studies. (2013). 1970 British Cohort Study: Twenty-Nine-Year Follow-Up, 1999-2000. 3rd Edition. Colchester, Essex: UK Data Archive, May 2013. SN: 5558. doi: 10.5255/UKDA-SN-5558-2

De Paola, M., \& Scoppa, V. (2015). Procrastination, Academic Success and the Effectiveness of Remedial Program. Journal of Economic Behavior and Organization, 115, 217-236. doi: 10.1016/j.jebo.2014.12.007

Dignath, C., \& Büttner, G. (2008). Components of Fostering Self-regulated Learn- 
ing Among Students: A Meta-analysis on Intervention Studies at Primary and Secondary School Level. Metacognition and Learning, 3(3), 231-264. doi: $10.1007 / \mathrm{s} 11409-008-9029-\mathrm{x}$

Dodgeon, B., Hancock, M., Johnson, J., \& Parsons, S. (2011). Deriving Highest Qualification in NCDS and BCS70 (Vol. 2011; Data Note No. 2011/1). London: Centre for Longitudinal Studies.

Duckworth, A. L., \& Seligman, M. E. P. (2006). Self-discipline Gives Girls the Edge: Gender in Self-discipline, Grades, and Achievement Test Scores. Journal of Educational Psychology, 98(1), 198-208. doi: 10.1037/0022-0663.98.1.198

Duckworth, A. L., Shulman, E., Mastronarde, A. J., Patrick, S. D., Zhang, J., \& Druckman, J. (2015). Will not Want: Self-control Rather than Motivation Explains Female Advantage in Report Card Grades. Learning and Individual Differences, 39, 13-23. doi: 10.1016/j.lindif.2015.02.006

Egan, M., Daly, M., Delaney, L., Boyce, C., \& Wood, A. M. (2017). Adolescent Conscientiousness Predicts Lower Lifetime Unemployment. Journal of Applied Psychology, 102(4), 700-709. doi: 10.1037/apl0000167

Ellison, G., \& Swanson, A. (2010). The Gender Gap in Secondary School Mathematics at High Achievement Levels: Evidence from the American Mathematics Competitions. The Journal of Economic Perspectives, 24(2), 109-128. doi: $10.1257 /$ jep.24.2.109

Else-Quest, N., Hyde, J., Goldsmith, H., \& van Hulle, C. (2006). Gender Differences in Temperament: A Meta-Analysis. Psychological Bulletin, 132(1), 33-72. doi: 10.1037/0033-2909.132.1.33

Eurostat. (2017). Population by Educational Attainment Level, Sex and Age (in Percent): edat_lfse_03 (accessed July 2017).

Fischer, F., Schult, J., \& Hell, B. (2013). Sex Differences in Secondary School Success: Why Female Students Perform Better. European Journal of Psychology of Education, 28, 529-543. doi: 10.1007/s10212-012-0127-4

Fouarge, D., Schils, T., \& de Grip, A. (2013). Why Do Low-Educated Workers 
Invest Less in Further Training? Applied Economics, 45(18), 2587-2601. doi: $10.1080 / 00036846.2012 .671926$

Friedman, H. S., Kern, M. L., \& Reynolds, C. (2010). Personality and Health, Subjective Well-Being, and Longevity. Journal of Personality, 78(1), 179-216. doi: 10.1111/j.1467-6494.2009.00613.x

Frijters, P., Johnston, D. W., \& Shields, M. A. (2014). Does Childhood Predict Adult Life Satisfaction? Evidence from British Cohort Surveys. Economic Journal, 124, F688-F719. doi: 10.1111/ecoj.12085

Fryer, R. G., \& Levitt, S. D. (2010). An Empirical Analysis of the Gender Gap in Mathematics. American Economic Journal: Applied Economics, 2(2), 210-240. doi: 10.1257 /app.2.2.210

Goldberg, L. R. (1993). The Structure of Phenotypic Personality Traits. American Psychologist, 48(1), 26-34.

Golsteyn, B. H., \& Schils, T. (2014). Gender Gaps in Primary School Achievement: A Decomposition into Endowments and Returns to IQ and Non-cognitive Factors. Economics of Education Review, 41, 176-187. doi: 10.1016/j.econedurev.2014 .04 .001

Heckman, J. J., Humphries, J. E., \& Kautz, T. (2014). The Myth of Achievement Tests: The GED and the Role of Character in American Life. Chicago: University of Chicago Press. doi: 10.1002/pam.21966

Heckman, J. J., Pinto, R., \& Savelyev, P. (2013). Understanding the Mechanisms Through Which an Influantial Early Childhood Program Boosted Adult Outcomes. American Economic Review, 103(6), 2052-2086. doi: 10.1257/ aer.103.6.2052

Hodis, F., Meyer, L. H., McClure, J., Weir, K. F., \& Walkey, F. H. (2011). A longitudinal investigation of secondary school achievement using Growth Mixture Modeling. Journal of Educational Psychology, 103, 312-323. doi: 10.1037/ $\mathrm{a} 0022547$

Hogan, R., \& Hogan, J. (2007). Hogan Personality Inventory Manual (3rd ed.). Tulsa, 
OK: Hogan Assessment Systems.

Husain, M., \& Millimet, D. L. (2009). The Mythical Boy Crisis? Economics of Education Review, 28, 38-48. doi: 10.1016/j.econedurev.2007.11.002

Johnson, J. L., \& Bloom, A. M. (1995). An Analysis of the Contribution of the Five Factors of Personality to Variance in Academic Performance. Personality and Individual Differences, 18(1), 127-133. doi: 10.1016/0191-8869(94)00109-6

Lai, F. (2010). Are Boys left Behind? The Evolution of the Gender Achievement Gap in Beijing's Middle Schools. Economics of Education Review, 29, 383-399. doi: 10.1016/j.econedurev.2009.07.009

Lebel, C., \& Beaulieu, C. (2011). Longitudinal Development of Human Brain Wiring Continues from Childhood into Adulthood. The Journal of Neuroscience, 31(30), 10937-10947. doi: 10.1523/JNEUROSCI.5302-10.2011

Lee, McInerney, D. M., Liem, G. A. D., \& Ortiga, Y. P. (2010). The Relationship Between Future Goals and Achievement Goal Orientations: An Intrinsic-extrinsic Motivation Perspective. Contemporary Educational Psychology, 35(4), 264-279. doi: $10.1016 /$ j.cedpsych.2010.04.004

Lee, Wadsworth, M. E. J., \& Hotopf, M. (2006). The Protective Role of Trait Anxiety: A Longitudinal Cohort Study. Psychological Medicine, 36, 345-351. doi: 10 $.1017 /$ S0033291705006847

Lundberg, S. (2013). The College Type: Personality and Educational Inequality. Journal of Labor Economics, 31 (3), 421-441. doi: 10.1086/671056

Lundborg, P. L., Nystedt, P., \& Rooth, D. (2014). Height and Earnings: The Role of Cognitive and Non-cognitive Skills. Journal of Human Resources, 49, 141-166. doi: $10.3368 / \mathrm{jhr} .49 .1 .141$

MacCann, C., Lipnevich, A. A., Burrus, J., \& Roberts, R. D. (2012). The best Years of our Lives? Coping with Stress Predicts School Grades, Life Satisfaction, and Feelings about High School. Learning and Individual Differences, 22(2), 235241.

Matthews, G., Deary, I. J., \& Whiteman, M. C. (2009). Personality Traits. Cambridge: 
Cambridge University Press.

McClure, J., Meyer, L. H., Garisch, J., Fischer, R., Weir, K. F., \& Walkey, F. H. (2011). Students' Attributions for Their Best and Worst Marks: Do They Relate to Achievement? Contemporary Educational Psychology, 36, 71-81. doi: 10.1016/ j.cedpsych.2010.11.001

McCrae, R. R., \& John, O. P. (1992). An Introduction to the Five-Factor Model and its Applications. Journal of Personality, 60(2), 175-215. doi: 10.1111/ j.1467-6494.1992.tb00970.x

Mendolia, S., \& Walker, I. (2014). The Effect of Personality Traits on Subject Choice and Performance in High School: Evidence from an English Cohort. Economics of Education Review, 43, 47-65. doi: 10.1016/j.econedurev.2014.09.004

Poropat, A. (2009). A Meta-Analysis of the Five-Factor Model of Personality and Academic Performance. Psychological Bulletin, 135(2), 322-338. doi: 10.1037/ a0014996

Poropat, A. (2014). Other-rated Personality and Academic Performance: Evidence and Implications. Learning and Individual Differences, 34, 24-32. doi: 10.1016/ j.lindif.2014.05.013

Prevoo, T., \& ter Weel, B. (2015). The Importance of Early Conscientiousness for Socio-Economic Outcomes: Evidence from the British Cohort Study. Oxford Economic Papers, 67(4), 918-948. doi: 10.1093/oep/gpv022

Reyna, V. F., Chapman, S. B., Dougherty, M. R., \& Confrey, J. (2012). The Adolescent Brain: Learning, Reasoning, and Decision Making. Washington, DC: American Psychological Association. doi: 10.1037/13493-000

Roberts, B. W., Smith, J., Jackson, J., \& Edmonds, G. (2009). Compensatory Conscientiousness and Health in Older Couples. Psychological Science, 20(5), 553-559. doi: 10.1111/j.1467-9280.2009.02339.x

Roberts, B. W., Walton, K., \& Bogg, T. (2005). Conscientiousness and Health Across the Life Course. Review of General Psychology, 9, 156-168. doi: 10.1037/ 1089-2680.9.2.156 
Robins, R. W., Fraley, R. C., Roberts, B. W., \& Trzesniewski, K. H. (2001). Plaster or Plasticity: Are Adult Work Experiences Associated with Personality Changes in Women? Journal of Personality, 69(4), 617-640.

Ryan, M., Delaney, L., \& Harmon, C. P. (2013). The Role of Noncognitive Traits in Undergraduate Study Behaviours. Economics of Education Review, 32, 181-195. doi: 10.1016/j.econedurev.2012.07.009

Saklofske, D., Austin, E., Mastoras, S., Beaton, L., \& Osborne, S. (2012). Relationships of Personality, Affect, Emotional Intelligence and Coping with Student Stress and Academic Success: Different Patterns of Association for Stress and Success. Learning and Individual Differences, 22(2), 251-257. doi: 10.1016/ j.lindif.2011.02.010

Schmitt, D. P., Realo, A., Voracek, M., \& Allik, J. (2008). Why Can't a Man Be More Like a Woman? Sex Differences in Big Five Personality Traits across 55 Cultures. Journal of Personality and Social Psychology, 94(1), 168-182. doi: 10.1037/0022-3514.94.1.168

Spengler, M., Brunner, M., Damian, R. I., Roberts, B. W., Lüdtke, O., \& Martin, R. (2015). Does it Help to be a Responsible Student? - Student Characteristics and Behaviors at Age 12 Predict Occupational Success 40 Years Later Over and Above Childhood IQ and Parental SES. Developmental Psychology, 51(9), 1329-1340. doi: http://dx.doi.org/10.1037/dev0000025

Spengler, M., Damian, R. I., \& Roberts, B. (2018). How you Behave in School Predicts Life Success Above and Beyond Family Background, Broad Traits, and Cognitive Ability. Journal of Personality and Social Psychology, 114(4), 620636. doi: $10.1037 / \mathrm{pspp} 0000185$

Spinath, B., Eckert, C., \& Steinmayr, R. (2014). Gender Differences in School Success: What are the Roles of Students's Intelligence, Personality and Motivation? Educational Research, 56(2), 230-243. doi: 10.1080/00131881.2014.898917

Spinath, B., Freudenthaler, H. H., \& Neubauer, A. C. (2010). Domain-specific School Achievement in Boys and Girls as Predicted by Intelligence, Personality and 
Motivation. Personality and Individual Differences, 48, 481-486. doi: 10.1016/ j.paid.2009.11.028

Steinberg, L. (2014). Age of Opportunity: Lessons from the new Science of Adolescence. Boston and New York.: Mariner Books: Houghton Mifflin Harcourt.

Steinmayr, R., \& Spinath, B. (2008). Sex Differences in School Achievement: What are the Roles of Personality and Achievement Motivation? European Journal of Personality, 22, 185-209. doi: 10.1002/per.676

Suls, J., \& Bunde, J. (2005). Anger, Anxiety, and Depression as Risk Factors for Cardiovascular Disease: The Problems and Implications of Overlapping Affective Dimensions. Psychological Bulletin, 131, 260-300. doi: 10.1037/0033-2909.131.2 .260

Turiano, N. a., Mroczek, D. K., Moynihan, J., \& Chapman, B. P. (2013). Big 5 Personality Traits and Interleukin-6: Evidence for "Healthy Neuroticism" in a US Population Sample. Brain, Behavior and Immunity, 28, 83-9. doi: 10.1016/ j.bbi. 2012.10 .020

Ursin, H., \& Eriksen, H. R. (2004, June). The Cognitive Activation Theory of Stress. Psychoneuroendocrinology, 29(5), 567-92. doi: 10.1016/S0306-4530(03)00091 $-\mathrm{X}$

Wehner, C. (2018). Too Scared to Achieve: The Relation Between Neuroticism, Conscientiousness and Socioeconomic Outcomes. Maastricht: Boekenplan. doi: $10.26481 /$ dis. $20180525 \mathrm{cw}$ 